\title{
FENOMENA MAHASISWA DALAM MELANJUTKAN PROGRAM PROFESI NERS
}

\author{
Ratna Dewi ${ }^{1)}$, Elva Tirta Yuli ${ }^{2}$ \\ Ilmu Keperawatan STIKes Fort De Kock, Bukittinggi \\ email : ratnadewi251183@g.mail.com
}

Submitted: 12-12-2016, Reviewer: 12-12-2016, Accepted: 14-12-2016

\begin{abstract}
ABSTRAK
Penelitian ini bertujuan untuk mengekplorasi pengalaman mahasiswa ners yang bukan alumni dari S1 Keperawatan Fort De Kock untuk melanjutkan program profesi ners di STIKes Fort De Kock Bukittinggi Tahun 2016. Menggunakan jenis penelitian kualitatif dengan pendekatan fenomenologi, Penelitian ini akan dilakukan di STIKes Fort De Kock Bukittinggi pada bulan Desember-Januari 2015. jumlah partisipannya sebanyak 5 orang dengan pengambilan partisipan menggunakan teknik purposive sampling.Hasil wawancara dianalisa dengan menggunakan metode colaizzi. Hasil wawancara didapatkan tema yaitu 1) Termotivasi melanjutkan profesi ners di FDK, 2) pengaruh dukungan sosial, 3) sumber informasinya menarik. Fenomena mahasiswa luar untuk melanjutkan pendidikan program profesi diSTIKes Fort De Kock saat ini sangat diminati karena mereka memilih Fort De Kock yang sudah memiliki akreditasi yang cukup bagus yaitu B, mereka memilih fort de kock jaga dipengaruhi oleh dukungan keluarga dan teman. Diharapkan program profesi ners di STIKes Fort De Kock bisa lebih baik lagi dan menjadi program profesi ners terbaik di Sumatra Barat.
\end{abstract}

Kata Kunci : Motivasi, Program Profesi Ners

\begin{abstract}
This study attempts to the exploration experience of ners students who are not taking bachelor degree of nursing kock to continue their practical in profession ners in in Health Science of fort de Kock Bukittinggi by year 2016. This study used the qualitative approach phenomenology. The number of partisipant in this study was five people who accaptenced as a participants, taken by using purposive sampling. The results of interviews were analysed by using colaizzi method. The results of the interviews obtained the theme such as 1 ) motivated continue profession ners in Fort De Kock Health Science, 2 ) the influence of social support, 3 ) the sources of the information interesting. The phenomenon of students out to go education a ners program in fort de kock Health Science currently a very popular, having a good accreditation $b$, they choose a fort de kock Health Science watch influenced by family and friends support. This study are expected to the ners profession program in Health Science fort de kock. It will be even better and become programmed profession ners best in West Sumatera. Eevery year many students nursing who wish to continue profession ners in Fort De Kock Health Science.
\end{abstract}

Keywords: Motivation, The Profession Ners 


\section{PENDAHULUAN}

Pendidikan tinggi keperawatan merupakan bagian dari pendidikan nasional yang mana pola pendidikan terdiri dari dua aspek yakni pendidikan akademik dan pendidikan profesi. Kedua tahap pendidikan keperawatan ini harus diikuti karena keduanya merupakan tahapan pendidikan yang terintegrasi sehingga tidak dapat dipisahkan satu dengan yang lainnya. Telah disepakati oleh semua institusi yang tergabung dalam Asosiasi Institusi Pendidikan Ners Indonesia bahwa lulusan profesi keperawatan yang siap bekerja atau telah memenuhi standar kompetensinya adalah lulusan Ners (Nurhidayah, 2011).

Pendidikan Ners adalah pendidikan yang bersifat AkademikProfesi yang dalam pelaksanaannya terdiri dari 2 (dua) tahapan yaitu tahapan pendidikan akademik dan tahapan pendidikan profesi. Program pendidikan ini mengacu pada metaparadigma keperawatan yang di sepakati di Indonesia dan mempunyai landasan ilmu pengetahuan dan landasan keprofesian yang kokoh. Pada pelaksanaannya sangat dipengaruhi oleh kemampuan pada proses pemahaman dan penguasaan ilmu pengetahuan dan teknologi keperawatan. Pada program pendidikan profesi terdapat masa penyesuaian profesional bagi peserta didik dalam bentuk pengalaman belajar klinik dan pengalaman belajar lapangan dengan menggunakan tatanan pelayanan kesehatan nyata,khususnya pelayanan keperawatan (Firman, 2009).

Program pendidikan profesi adakalanya juga disebut sebagai proses pembelajaran klinik. Istilah ini muncul terkait dengan pelaksanaan pendidikan profesi yang sepenuhnya dilaksanakan di lahan praktik seperti rumah sakit, puskesmas, klinik bersalin, panti werdha, dan keluarga serta masyarakat atau komunitas (Nurhidayah, 2011).

Pendidikan Program Profesi Ners di Stikes Fort De Kock Bukittinggi sangat banyak diminati oleh mahasiswa keperawatan baik yang dari FDK sendiri maupun dari luar FDK yang ingin melanjutkan program profesi dan ingin menjadi perawat profesional nantinya dimasa depan. Program profesi sudah ada izin penyelenggaraannya di stikes fort de kock No.267/D/O/2008 tanggal 31 Desember 2008 yang telah terakreditasi BAN-PT pada tahun 2012 juga sudah di reakreditasi oleh LAM-PT Kes pada tanggal 23 hingga 26 November 2014 dengan predikat akreditasi B oleh LAM-PTKes, sesuai SK BAN PT nomor : 071/AK/BANPT/Akred/PN/II/2015. Program profesi sendiri di stikes fort de kock menjadi urutan ke 4 setelah program ilmu kesehatan masyarakat pada bulan juli 2008, program ilmu keperawatan bulan September 2008 dan kemudian program studi diploma III kebidanan pada tahun ajaran 2008 / 2009.

Profesi nursing di Indonesia yang tergolong masih muda dibandingkan dengan negara Barat memang tertinggal jauh. Bahkan di antara negara-negar Asia sekalipun. Meskipun demikian, geliat perubahan yang dimulai sejak tujuh tahun terakhir ditanah air merupakan upaya positif yang sudah pasti memerlukan dukungan semua pihak. 
Tetapi yang lebih penting adalah dukungan pemikiran-pemikiran kritis terutama dari nurses itu sendiri (Hardy, 2007).

World Healt Organisation (WHO) 2005 menunjukkan bahwa dunia kekurangan 2 juta perawat, baik di AS, Eropa, Australia dan Timur Tengah. Kebutuhan tenaga perawat di Negara maju seperti Amerika, Canada, Erofa, Australia, Jepang, dan Timur tengah melonjak dengan drastis sejak tahun 1980. Untuk seluruh Negara maju diatas kebutuhan perawat diperkirakan mencapai 1 juta perawat pada tahuan 2020. Kebutuhan tenaga di Amerika sendiri di tahun 1980 sekitar 200.000 perawat dan kebutuhan ini akan melonjak menjadi 500.000 perawat ditahun 2020 untuk mendukung kebutuhan pelayanan kesehatan di Amerika (Rijandi, 2005).

Di Indonesia, keperawatan sebagai suatu profesi telah disepakati pada lokakarya nasional tahun 1983. Keperawatan didefenisikan sebagai seseorang yang berperan dalam merawat atau memelihara, membantu dengan melindungi seseorang karena sakit, luka dan proses penuaan (Budiono \& Sumirah, 2015)

Di Sumatera Barat sendiri pendidikan dibidang keperawatan juga sangat diminati. Lebih dari 1500 mahasiswa keperawatan tersebar di PT negeri maupun swasta di Sumbar, tapi $20 \%$ dari mereka belum mau melanjutkan keprofesi ners (Jasvita, 2011).

Motivasi memegang peranan penting dalam pencapaian prestasi. Salah satu bentuk nyata peran motivasi terhadap pencapaian prestasi adalah tercermin pada diri seorang mahasiswa dalam menempuh pendidikan. Seorang mahasiswa dalam menempuh jenjang pendidikan tentunya memiliki dorongan untuk mencapai prestasi yang setinggi-tingginya dalam belajar. Motivasi yang ada dalam diri kita akan memunculkan keinginan, menggerakan, dan mengarahkan tingkah laku. Semakin tinggi motivasi seseorang, semakin tinggi intensitas perilakunya (Poerwodarminto, 2006).

Upoyo dan Sumarwati (2011) telah melakukan penelitian terkait tentang analisis faktor-faktor yang mempengaruhi motivasi mahasiswa Profesi Ners jurusan keperawatan Unsoed Purwokerto. Hasil penelitian menunjukkan bahwa sebagian besar mahasiswa mempunyai motivasi yang tinggi dalam mengikuti Profesi Ners. Faktor yang berpengaruh secara signifikan terhadap tingkat motivasi mahasiswa adalah dorongan internal, faktor beban tugas, dan lingkungan rumah sakit. Faktor lain seperti lama pelaksanaan, metode, peran pembimbing klinik, dan peran pembimbing akademik belum memberikan pengaruh yang signifikan terhadap peningkatan motivasi mahasiswa profesi.

Hasil penelitian yang dilakukan pada tanggal 23 Oktober 2013 di Program Studi Ilmu Keperawatan Universitas Riau menunjukkan bahwa data mahasiswa dari tahun 2008-2009 tercatat sekitar $87,12 \%$ mahasiswa yang melanjutkan ke tahap Profesi Ners, sedangkan sekitar $12,87 \%$ tidak melanjutkan ke tahap Program Ners. Berdasarkan data tersebut dapat disimpulkan bahwa cukup banyak mahasiswa yang tidak melanjutkan Profesi Ners.

Dari hasil wawancara yang sudah pernah peneliti sendiri lakukan di STIKes Fort De Kok (FDK) dengan mahasiswa S1 keperawatan 
yang melanjutkan program profesi ners yaitu mereka kebanyakan menjawab "mereka melanjutkan profesi ners di stikes FDK karena akreditasinya yang sudah bagus yaitu B “.

Dari latar belakang diatas peneliti tertarik untuk melakukan penelitian yaitu kenapa mahasiswa S1 keperawatan dari luar Fort De Kock mau melanjutkan profesi ners di Stikes Fort De Kock Bukittinggi tahun 2015.

Mahasiswa adalah orang yang belajar diperguruan tinggi baik di Universitas, institut atau akademi. Mereka terdaftar sebagai murid diperguruan tinggi dapat disebut sebagai mahasiswa. Jadi mahasiswa S1 keperawatan yaitu murid yang sedang mengenyam pendidikan dengan jurusan sarjana keperawatan.

1. Proses

Motivasi adalah proses yang menjelaskan intensitas, arah dan ketekunan seorang individu untuk mencapai suatu tujuannya.

2. Out put

\begin{tabular}{lrr}
\multicolumn{1}{c}{ Profesi } & Ners & adalah \\
pendidikan lanjutan & dari \\
pendidikan akademik & pada \\
program studi ilmu keperawatan \\
(S1) yang dilaksanakan selama 1 \\
tahun dimana ristem \\
pembelajaran r dilakukan \\
sepenuhnya dilahan praktik.
\end{tabular}

METODE PENELITIAN

Dalam penelitian ini, peneliti menggunakan jenis penelitian kualitatif dengan pendekatan fenomenologi. Pendekatan fenomenologi adalah pengalaman yang bersifat universal yang dilalami oleh seorang individu terhadap suatu fenonema yang dialaminya dalam kehidupan sehari-hari (Afriyanti \& Rahmawati 2014, p.66). jumlah partisipannya sebanyak 5 orang dengan pengambilan partisipan menggunakan teknik purposive sampling

\section{Hasil dan Pembahasan}

Bagian ini menjelaskan tentang hasil penelitian yang telah dilakukan yang bertujuan untuk memperoleh pemahaman mendalam tentang Fenomena motivasi mahasiswa ners dalam melanjutkan program profesi ners di STIKes Fort De Kock Bukittinggi. Penelitian ini menghasilkan 3 tema utama fenomena motivasi mahasiswa ners dalam melanjutkan program profesi ners di STIKes Fort De Kock. Hasil penelitian ini diuraikan menjadidua bagian. Bagian pertama terdiri dari uraian karakteristik partisipan yang terlibat dalam penelitian ini. Bagian kedua menguraikan tentang analisis data yang muncul. 


\section{Gambaran Karakteristik Partisipan}

Partisipan yang berpartisipasi dalam penelitian ini sebanyak 5 orang. Deskripsi partisipan penelitian secara lengkap bisa dilihat pada tabel

Tabel

Partisipan Penelitian

\begin{tabular}{llll}
\hline Partisipan/P & Usia & Agama & Asal kampus sebelumnya \\
\hline Nn. P / P1 & 23 & Islam & Universitas J \\
Nn. R / P2 & 25 & Islam & Stikes H \\
Nn. H / P3 & 27 & Islam & Stikes H \\
Nn. A / P4 & 25 & Islam & Stikes M \\
Nn.W / P5 & 25 & Islam & Stikes H \\
\hline
\end{tabular}

Semua partisipan yang berpartisi dalam penelitian ini beragama islam dan berasal dari kampus yang berbeda-beda sebelum kuliah di STIKes Fort De Kock Bukittinggi ini. Pada penelitian ini ditemukan alasan mengapa mahasiswa yang bukan alumni dari

\section{A. Hasil Wawancara Mendalam/ Analisis Tema \\ Berdasarkan} hasil

wawancara mendalam pada penelitian ini diperoleh empat tema yang merupakan motivasi mahasiswa mahasiswa yang bukan alumni STIKes Fort De Kock dalam melanjutkan program profesi di STKes Fort De Kck, terdiri dari pertama motivasi dalam pendidikan, dukungan sosial, sumber informasi, dan kendala atau hambatan dalam menjalani pendidikan profesi.
STIKes Fort De Kock memilih STIKes Fort Dock menjadi lanjutan untuk mengambil profesi ners. Alasannya yaitu karena Fort de kock memilik akreditasi yang bagus yaitu $B$ dan juga dukungan keluarga dan teman sebaya juga berperan dalam pemilihahan Stikes ini.

\section{Termotivasi Melanjutkan Profesi Ners di STIKes Fort De Kock}

\section{a. Motivasi Internal}

Pada umumnya partisipan pada penelitian memilih STIKes Fort De Kock karena beberapa faktor, salah satunya yaitu faktor internal dan juga partisipan mempunyai alasan sendiri memilih STIKes Fort De Kock sebagai lanjutan profesi. Berikut pernyataan partisipan:

"Menurut saya alasan saya memilih STIKes Fort De Kock hm.... karena untuk mencari pengalaman baru dan suasana baru dari kampus 
sebelumnya makanya saya memilih STIKes Fortt De Kock “(P2).

$$
\begin{aligned}
& \text { “Hmm..... pengalaman saya } \\
& \text { dalam menjalani profesi ners } \\
& \text { sangat.... sangat lancar dan } \\
& \text { menyenangkan"(P2) } \\
& \text { “ ya kampusnya yang bagus dan } \\
& \text { teman-temannya yang baik dan juga } \\
& \text { untuk mencari suasana baru dari } \\
& \text { tempat sebelumnya dek”(P5). }
\end{aligned}
$$

\section{b. Motivasi Ekternal}

Partisipan selanjutnya ada juga yang mengatakan dukungan dari luar yang banyak membuat mereka memilih STIKes Fort De Kock ini sebagai lanjutan untuk mengambil profesi karena jika memilih suatu intansi pasti kita lihat mutunya terlebih dahulu. Berikut pernyataan mereka:

"karena akreditasinya yang

sudah $B$, kampusnya sepertinya menyenangkan" $(P 1)$.

"dosennya yang sudah berpendidikan tinggi dan juga fasilitasnya yang bagus serta lulusan distikes fdk memiliki kopetensi yang baik”(P1)

"adalah dek, akreditasinya yang bagus, dosenya juga, gedungnya yang megah berdiri diatas bukit pokoknya cantik dipandang gitulah haa"(P2).

"oooo sangat bagus dan dosen nya juga baik dan juga dosen-dosen disini sudah ahli dibidangnya masing-masing gitu dek"(P2).

“ Yang pertama yaitu STIKes Fort De Kock ooo mutunya bagus dan juga akreditasinya sudah $B$ sudah bagus"(P3).
“ hmmm.. menurut sayak fasilitasnya cukup lengkap,terutama dilabor, alat-alatnya lengkap jadi pas ujian labor kita tau semua alatalat apa saja yang kita gunakan, kantinnya juga bersih, tempat santai juga nyaman dan perkarangan nya juga luas"(P3).

" Saya memilih Fort De Kock sebagai lanjutan untuk profesi ners karena Fort De Kock akreditasinya sudah B kalau di J tu C “(P4).

“ gini dek, disini kami belajar kami selalu dibimbing oleh dosen-dosen dan selalu mengarahkan kami jika tindakan yang kami lakukan salah dalam praktek supaya nantinya pas dinas tidak melakukan kesalahan lagi gituu haa.. "(P4).

“ karena akreditasi, akreditasinya B “(P5).

\section{Pengaruh Dukungan Sosial}

Dukungan sosial sangat berperan penting dalam kehidupan kita apalagi dalam pemilihahan instansi atau tempat kuliah karena jika kita salah pilih bisa fatal akibatnya. Makanya disini sangat dibutuhkan dukungan sosial.

\section{a. Dukungan Keluarga}

Dukungan keluarga adalah dukungan yang sangat dibutuhkan oleh seorang anak jika sianak bimbang dalam suatu pemilihan, keluarga sangat berperan banyak disini terutama orang tua kita. Berikut pernyataannya:

$$
\begin{aligned}
& \text { " tentu keluarga sangat } \\
& \text { berperan”(Pl). } \\
& \text { "dukungannya sih berupa } \\
& \text { motivasi dan pengarahan dari } \\
& \text { orang tua dan satu lagi uang- }
\end{aligned}
$$


uang nya juga. teman yang sudah kuliah

Hehehehe..."(P2).

“ Kalau untuk keluarga hanya mendukung apa keputusan dari saya, kalau teman aaa sangat berperan dalam menetukan instansi diSTIKes Fort aaa instansi yang akan dipilih yaitu STIKes Fort De Kock ada teman yang menyarankan memilih STIKes Fort De Kock sih "(P3)

" ya dukungan nya sih cuma memeberikan motivasi dan arahan untuk kakak ditempat yang baru dan materi pastinya dan juga orangtua ikut apa kata anak nya saja hahahaa..."(P4).

“ kalau keluarga memfasilitasi kakak dari sana kesini aja, kalau untuk masalah kampus ini teman “(P5).

\section{b. Dukungan Teman Sebaya}

Teman merupakan orang yang paling lama berada disekitar kita selain keluarga, teman juga menjadi salah satu alasan mengapa kita memilih STIKes Fort de Kock untuk menjadi lanjutan profesi ners. Berikut pernyataannya:

“ hmmm... kalau teman lebih berperan karena ooooo... takut nantinya kalau salah pilih stikes malahan kedepannya akan mempersulit saya dalam dunia kerja”(P1).

"kalau dari teman sih berupa masukan makanya kakak memilih stikes ini”(P2).

"teman menyarankan agar masuk stikes fdk karena stikesnya bagus dan sudah terakreditasi juga,dan juga sudah banyak teman-
disana"(P3).

“ kalau teman sih banyak sekali contohnya saja tentang stikes dan ngajak kuliah disini juga teman dan kakak ikut-ikutan aja kuliah, sebenarnya kakak udah capek kuliah dek tapi karena ajakan teman ya kakak kuliah juga akhirnya”(P4).

" ya dukungan teman lebih banyak ajakan sih untuk kuliah disini"(P5).

\section{Sumber Informasi}

Sumber informasi merupakan suatu alat untuk melihat dunia luar misalnya tempat, gedung, bertemu orang dan lain-lain. Berikut pernyataannya.

"hmmm.... setelah dapat info dari teman, saya melihat tentang kampus ini di internet dan juga brosur yang saya dapatkan"(P1).

"dari internet dan brosur”(P2).

"udah juga sih dari internet tapi belum begitu kali pas dikasih tau teman baru kakak percaya gitu dek. Hehehe...."(P3).

“ hmmm... dari internet dan bosur, pas kakak lihat diinternet kampus nya bagus sekali dek”(P4).

“Hmmm.... dari internet”(P5). 


\section{A. Intrepretasi Hasil Penelitian}

Penelitian ini menemukan tiga tema untuk mengungkapkan fenomena motivasi mahasiswa ners dalam melanjutkan program profesi ners di STIKes Fort De Kock Bukittinggi. Gambaran tentang motivasi terhadap keadaan pasca dalam menjalankan ners teridentifikasi pada tema pertama yaitu termotivasi melanjutkan program profesi ners di FDK. Gambaran partisipan terhadap dukungan yang didapatkan teridentifikasi dari tema kedua yaitu dukungan sosial. Gambaran tentang partisipan mengetahui tentang kampus dari internet, brosur dan teman teridentifikasi dari tema ketiga yaitu sumber informasinya yang menarik.

\section{Tema 1 : Termotivasi Melanjutkan Program Profesi Ners di STIKes Fort de Kock}

Hasil penelitian ini menemukan bahwa partisipan mencari pengalaman baru untuk melanjutkan program profesi ners di STIKes Fort De Kock.

Hasil ini dijelaskan oleh Suarli (2002) yang menyatakan motivasi merupakan karakteristik psikologis manusia yang memberikan konstibusi pada tingkat komitmen seseorang dan mendorong seseorang untuk melakukan sesuatu yang diinginkan.

Hasil penelitian yang dilakukan Siswanto dkk (2014) tentang faktor-faktor yang berhubungan dengan motivasi mahasiswa untuk melanjutkan profesi ners diUniversitas Riau menunjukkan bahwa motivasi memegang peranan penting dalam pencapain prestasi. Salah satu bentuk nyata peran motivasi terhadap pencapain prestasi adalah cerminan pada diri seseorang mahasiswa dalam menempuh pendidikan. Seseorang mahasiswa dalam menempuh jenjang pendidikan tentunya memiliki dorongan untuk mencapai prestasi yang setinggi-tingginya dalam belajar.

Penelitian yang dilakukan Upoyo dan Sumarwati (2011) telah melakukan penelitian terkait tentang analisis faktor-faktor yang mempengaruhi motivasi mahasiswa profesi ners jurusan keperawatan Unsoed Purwokerto. Hasil penelitian menunjukkan bahwa sebagian mahasiswa mempunyai motivasi yang tinggi dalam mengikuti profesi ners. Faktor berpengaruh secara signifikan terhadap tingkat motivasi mahasiswa adalah dorongan internal.

Analisa peneliti memang dibutuhkan dorongan atau motivasi internal dan ekternal untuk memilih sesuatu yang kita inginkan atau yang ingin kita capai.

\section{Tema 2 : Pengaruh Dukungan sosial \\ Dukungan sosial}

terutama dukungan teman sebaya beserta keluarga yang positif dapat mempengaruhi prilaku orang lain, termasuk minat seseorang terhadap suatu objek.

Berdasarkan studi pendahuluan yang dilakukan oleh Sari dan Susilowati (2014) terhadap mahasiswa STIKES Aisyiyah Surakarta program studi ilmu keperawatan semester 8 sebanyak 20 orang diperoleh data sebagian besar (16 orang) mengatakan mereka sling menyemangati, mendukung dan memberi gambaran yang positif tentang program profesi ners, selain itu mereka juga saling membantu dalam 
pemecahan solusi ketika ada mahasiswa yang dalam masalah karena mereka sudah merasa seperti keluarga mereka.

Lingkungan kampus merupakan lingkungan yang dapat mempberikan pengaruh yang besar terhadap mahasiswa. Mahasiswa program ners, terutama yang jalur reguler, sebagian besar usianya sam atau sebaya. Laursen (2005) menjelaskan bahwa teman sebaya merupakan faktor yang sangat berpengaruh terhadap kehidupan pada masa-masa remaja, karena pada kenyataannya remaja dalam masyarakat modren seperti sekarang ini menghabiskan sebagian waktunya bersama teman sebaya mereka.

Analisa peneliti partisipan banyak mendapat dukungan dari teman sebaya dan orang tua tapi yang lebih banyak dukungan dari teman sebaya untuk pemilihan instansi yang mereka pilih ini.

\section{Tema 3 : Sumber informasinya Menarik}

Sumber informasi sangat penting karena dengan adanya informasi seseorang bisa mengetahui apa yang terjadi. Salah satu sumber informasi yaitu internet, internet bisa memberi informasi apa saja yang kita butuhkan. Contohnya jika kita ingin mengetahui tentang profil sebuah kampus kita bisa mencek nya diinternet bahkan data yang kita butuhkan lengkap didalamnya.

Sumber informasi merupakan penyedia sekumpulan informasi yang telah di kelompokan berdasarkan masing - masing kategori . sumber informasi bisa berupa Perpustakaan, Majalah, Surat Kabar dan Website.

Pada mulanya akses informasi hanya media cetak seperti buku dan majalah. Namun saat ini diIndonesia, bahan pustaka tersebut pemanfaatannya terjadi pergeseran , terutama dikaitkan dengan tingginya harga buku dan majalah ilmiah serta penyediaan dana pengadaan bahan pustaka yang terbatas. Internet sebagai media muktahir, dianggap sebagai solusi yang daapt membantu mengatasi masalah tersebut . selain itu internet juga bisa diakses kapan saja dan dimana saja tanpa batas selama terhubung dengan jaringan (Suprihatin 2009).

Penelitian yang dilakukan oleh Ardianto bahwa dalam membangun SDM dunia pendidikan dituntut untuk mmampu mengikuti (update) perkembangan aplikasi IPTEK didunia industri agar lulusannya memiliki kompetensi yang sesuai dengan kebutuhan dasar. Dari fakta tersebut salah satu caranya untuk mampu mengikuti perkembangan IPTEK yang cepat adalah selalu akses informasi yang up to date dan semua itu dadapt didapat melalui internet. Kekayaaan informasi yang sekarang tersedia diinternet telah lebih mencapai harapan dan bahkan imajinasi para penemu sistemnya. Melalui internet dapat diakses sumber-sumber informasi tanpa batas dan aktual dengan sangat cepat. Adanya internet memungkinan seseorang di Indonesia bisa mengakses library di Amerika Serikat dalam bentuk digital library. Sudah banyak pengalaman tentang pemnafaatan internet dalam penelitian dan penyelesaian tugas akhir mahasiswa. Tukar menukar informasi atau tanya jawab dengan pakar juga dapat dilakukan di internet. Tanpa teknologi internet banyak tugas akhir dan thesis atau bahkan disertasi yang bahkan membutuhkan waktu lebih banyak untuk menyelesaikannya.

Motivasi adalah

karakteristik psikologis manusia yang 
memberi kontribusi pada tingkat komitmen seseorang. Sedangkan menurut (Ngalim Purwanto, 2000) motivasi adalah sesuatu yang mendorong seseorang untuk melakukan sesuatu dan menurut (Sortell dan Kauzny, 1994) mengartikan motivasi sebagai perasaan atau pikiran yang mendorong seseorang melakukan atau menjalankan kekuasaan, terutama dalam berprilaku (Suarly dan Bahtiar, 2002,p.29).

Program profesi merupakan prosestranformasi dari mahasisiwa menjadi seorang perawat profesional. Dengan kata lain , peserta didik akan memiliki prilaku sebagai perawat profesional setelah program profesi . Dalam fase ini , mahasisiwa mendapat kesempatan beradaptasi . pada perannya sebagai perawat profesional dalam masyarakat keperawatan dan lingkungan peleyanan/ asuhan keperawatan (Nursallam 2013, p.256) .

Pada dasarnya terdapat banyak hal yang mempengaruhi minat mahasiswa untukmelanjutkan pendidikan profesi. Menurut Ismani (2001) minat ini dipengaruhi olehfaktor keluarga, keinginan untuk meningkatkan pengetahuan, tuntutan pekerjaan,kondisi sosial ekonomi, dan untuk mendapatkan legilasi. Namun, selain itu ada satu lagihal yang sangat penting yaitu motivasi dari diri mahasiswa tersebut untuk melanjutkanpendidikan profesi. Motivasi adalah suat $\mathrm{u}$ dorongan dari dalam diri seseorang yangmenyebabkan orang tersebut melakukan kegiatan-kegiatan tertentu guna mencapai suatutujuan (Notoatmodjo, 2005).

Study pendahuluan yang dilakukan oleh siswanto dkk tentang faktor-faktor yang berhubungan dengan motivasi mahasiswa untuk melanjutkan profesi ners pada tanggal 23 Oktober 1013 diprogram study ilmu keperawatan Universitas Riau menunjukkan bahwa data mahasiswa dari tahun 2008-2009 tercatat $87,12 \%$ mahasiswa yang mealnjuttkan ketahap profesi ners, sedangkan sekitar $12,87 \%$ tidak melanjutkan ketahap profesi ners.

Berdasarkan penelitian pendahuluan yang dilakukan oleh Rahmawati (2011) data dari fakultas ilmu kesehatan Universitas Muhammadiyah Surakarta bahwa mahasiswa sarjana keperawatan angkatan 2003 sejumlah 34 mahasiswa, kemudian yang mengikuti program profesi ners adalah 28 mahasiswa, sedangkan pada angkatan 2004 sejumlah 56 mahasiswa, yang mengikuti program profesi ners adalah 38 mahasiswa, angkatan 2005 sejumlah 84 mahasiswa, yang mengikuti program profesi ners adalah 48 mahasiswa, dan dari angkatan 2006 sejumlah 106 mahasiswa, yang mengikuti program profesi ners adalah 63 mahasiswa.

Penelitian yang

dilakukan Santrok (2004) selama tiga dekade menunjukkan bahwa sahabat dapat menjadi sumbersumber kognitif dan emosi sejak masa kanak-kanak sampai dengan masa tua. Selain itu bahwa dukungan teman sebaya banyak membantu atau memberikan keuntungan kepada anak-anak yang memiliki problem sosial dan problem keluarga, memberikan pelatihan keterampilan sosial dan dapat membantu memperbaiki iklim sekolah.

Sedangkan data mengenai minat mahasiswa untuk mengikuti program profesi ners, 11 mahasiawa 
menyampaikan bahwa mereka berminat untuk mengikuti program profesiners dan 9 mahasiswa mengatakan masih bingung dan ragu-ragu untuk mengikuti program profesi ners.

Berdasarkan analisis peneliti bahwa dukungan sosisl teman sebaya sangat berperan karena dapat memberikan pengaruh yang besar terhadap mahaswa itu sendiri.

Analisa peneliti bahwa yang menjadi hambatan bagi mahasiswa dalam menjalankan program profesi ners adalah tugas yang banya dan dan masalah libur.

\section{B. Keterbatasan Dalam Penelitian}

1. Keterbatasan peneliti merupakan intrumen utama

Penelitian ini merupakan pengalaman utama bagi peneliti. Penelitian ini peneliti sendiri sebagai intrumen utama dalam pengumpulan data, maka pengalaman dan kemampuan peneliti sendiri dalam wawancara banyak mempengaruhi hasil yang didapat. Kemungkinan banyak data yang didapat atau digali bila peneliti meningkatkan kemampuan mengembangkan pertanyaan saat dilakukan wawancara mendalam tentang motivasi partisipan. Ditambah lagi penelitian ini membahas tentang motivasi dalam melanjutkan pendidikan profesi ners bagi mahasiswa yang bukan alumni dari STIKes Fort De Kock Bukittinggi.

2. Situasi saat wawancara kurang mendukung Kegiatan wawancara dilakukan diposko PKLT mahasiswa Ners yang menjalani siklus komunitas. Ini dirasakan kurang nyaman karena diposko orang terlalu ramai dan berisik.
Hal ini diantisipasi oleh peneliti dengan berusaha melakukan wawancara dengan pendekatan jarak antara penelirti dengan partisipan dan mendekattkan alat perekam suara kepartisipan.

\section{SIMPULAN}

$\begin{array}{ccc} & \text { Hasil penelitian ditemukan } 3 \\ \text { tema } & \text { yaitu 1) } & \text { Termotivasi }\end{array}$ Melanjutkan Profesi Ners, 2) Pengaruh Dukungan Sosial, 3) Sumber Informasinya Menarik. Gambaran fenomena yang terjadi di STIKes Fort De Kock Bukittinggi saat ini adalah banyak nya orang yang ingin melanjutkan pendidikan khususnya dibagian kesehatan. Dan program yang paling banyak diminati untuk saat ini yaitu program profesi ners yang mana profesi ners di STIKes Fort de Kock sendiri sudah terakreditasi B, dan fasilitas yang diberikan oleh pihak kampus juga sangat bagus untuk mahasiswa nya. Program profesi ners di STIKes Fort De Kock sendiri terbuka untuk umum dan reguler, khususnya bagi ibuk-ibuk yang sudah bekerja dan ingin melanjutkan profesi ners di STIKes Fort De Kock.

Program profesi ners di STIKes Fort De Kock bukan hanya diminati oleh oleh mahasiswa nya sendiri tapi mahasiswa dari kampus lain juga ingin menimba ilmu profesi disini. Bukan hanya dari sekitaran Bukittinggi saja tapi dari Padang, Jambi, Riau, Palembang juga berminat untuk melanjutkan program profesi ners di STIKes Fort De Kock ini.

Pada hasil penelitian ini teridentifikasi bahwa yang menjadi dorongan bagi mahasiswa/i dari kampus lain untuk melanjutkan profesi ners di STIKes Fort De Kock adalah akreditasi profesi ners yang sudah B, 
pengaruh dari teman dan poin plus nya yaitu fasilitas yang diberikan kampus bagus. Diharapkan kepada mahasiswa semester VII untuk dapat melanjutkan ke program profesi ners agar dapat menjadi perawat profesional dan mempunyai skill yang bermutu. Ners lebih dari pekerjaan yang mengedepankan pelayanan klien untuk memperoleh kepuasan. Dengan program profesi ners diharapkan mahasiswa akan lebih terampil, aktif, mandiri, dan dapat menyelesaikan masalah secara ilmiah. kepada instansi terkait agar memberikan informasi informasi yang bermanfaat mengenai program profesi Ners untuk menjadi acuan bagi para mahasiswa yang akan melanjutkan Profesi Ners dan selanjutnya hasil penelitian ini dapat dijadikan data awal atau referensi dalam penelitian selanjutnya dengan lebih banyak responden dan yang menjadi respondennya jangan hanya wanita tapi laki-laki juga dijadikan sebagai respondennya.

\section{UCAPAN TERIMAKASIH}

Terimakasih yang tak terhingga kepada Ketua Stikes Fort De Kock yang telah memberikan izin penelitian khususnya bagi dosen pemula untuk menambah pengalaman dosen pemula dalam melaksanakan tri dharma perguruan tinggi dalam bidang penelitian dan seluruh teman-teman seperjuangan khususnya prodi Profesi ners yang telah banyak membantu dan memfasilitasi peneliti dalam melakukan penelitian, dan semua pihak yang telah membantu. Terimakasih juga Mahasiswa profesi ners yang telah bersedia menjadi partisipan. Peneliti berharap Allah SWT berkenan membalas segala kebaikan semua pihak yang telah membantu. Semoga penelitian ini membawa manfaat bagi pengembangan ilmu Profesi Ners khususnya.

\section{REFERENSI}

Afriyanti Yati, Rahmawati.I.N.( 2014). Metodologi Penelitian Kualitatif dalam Riset Keperawatan. Raja Wali Pers, Jakarta.

Budiono dan Pertami Sumira Budi.( 2015). Konsep Dasar Keperawatan, Budi Medika, Jakarta.

Djamarah Syaiful. (2008). Psikologi Belajar, Rineka Cipta, Jakarta.

Ermiyati. (2007). Buku Panduan Program Profesi Ners Program Studi Ilmu Keperawatan, FK USU, Medan.

Hamzah. (2008). Teori Motivasi dan Pengukuran Bumi, Bumi Aksara. Jakarta.

Hidayat. Aziz. Alimul. (2004). Penagantar konsep dasar keperawatan, Salemba Medika, Jakarta.

Faktor Yang Berhubungan Dengan Minat Mahasiswa Program Studi S1 Keperawatan Untuk Mengikuti Program Ners Di Stikes Nani Hasanuddin Makasar, Jurnal Unhas, 3( 4), 55-60

Mudyaharjo. (2002). Filsafah Ilmu Pendidikan, PT Renika Cipta, Bandung. 
Nasir, Muhith Abdul,IdePutri. (2011). Metodologi Penelitian

Kesehatan. Nuha Medika, Yogyakarta.

Notoatmodjo. (2007). Promosi Kesehatan dan Ilmu Prilaku. Rineka Cipta, Jakarta

$\begin{array}{cr}\text { Nursalam 2002, } & \text { Menajemen } \\ \text { Keperawatan, } & \text { Salemba } \\ \text { Medika. Jakarta. } & \end{array}$

Nursalam, 2013, Manajemen Keperawatan: Aplikasi dalam Praktik Keperawatan Profesional, Salemba Medika, Jakarta.

Nursalam, 2013, Metodologi Penelitian Ilmu Keperawatan, Salemba Medika, Jakarta.

Rahmawati Nur \& Widodo Arif, 2011, Faktor-Faktor Yang Mempengaruhi Motivasi Mahasiswa Sarjana Keperawatan Untuk Melanjutkan Pendidikan Profesi Ners Di Universitas Miuhammadiyah Surakarta. https://publikasiilmiah.ums.ac id/bitstream/handle/11617/36 80/NUR\%20RAHMAWATI $\% 20 \% 20 \mathrm{ARIF} \% 20 \mathrm{WIDODO}$ $\%$ 20Fix\%20bgt.pdf?sequence $=1$

Siswanto Fauzi, Erwin \& Woferst Rismadevi. (2014) FaktorFaktor Yang Berhubungan Dengan Motivasi Mahasiswa Untuk Melanjutkan Program Profesi,JOMPSIK,Voll,No.2, Hal1-10. http://www.google.com/url?sa $=\mathrm{t} \& \mathrm{rct}=\mathrm{j} \& \mathrm{q}=\&$ esrc $=\mathrm{s} \&$ source =web\&cd=1\&ved=0ahUKEw jzq6ujyJLOAhXJNI8KHQM-

STIKes FDK. (2014). Buku Panduan Akademik Sekolah Tinggi Ilmu Kesehatan (STIKes Fort De KockBukittinggi ), STIKes FDK.

Suarli dan Bahtiar. (2002). Manajemen Keperawatan dengan pendekatan praktis, PT Gelora Aksara Pratama, Tasikmalaya.

Sujarweni Wiratna. (2014). Metodologi Penelitian Keperawatan, Gava Media. Yogyakarta.

Susilowati Tri \& Mustika Irma. (2014). Hubungan Dukungan Teman Sebaya (Peer Group) Dengan Minat Mahasiswa Mengikuti Program Profesi Ners Di Stikes Aisyiyah Surakarta, Gaster Vol XI, No.2. https://www.google.com/searc $\mathrm{h}$ ?q=jurnal hubungan dukungan teman US:official\&client=firefoxbeta\&channel=sb

Winardi. (2002). Motivasi dan pemotivasian dalam manajemen, PT Raja Grafindo Persada, Jakarta

Jasvita Yutika. (2011). Hubungan Pengetahuan, Motivasi, Dan Status Ekonomi Mahasiswa Semester VII Dengan Minat Melanjutkan Ke Programprofesi Ners Di Stikes FDK Bukittinggi Tahun 2011, Stikes FDK Jurusan Ilmu Keperawatan, Skripsi. 
